\title{
AN EXPLORATORY STUDY OF FINANCIAL MANAGEMENT PRACTICES AMONG GHANAIAN HOUSEHOLDS
}

\author{
Redeemer Yao Krah ${ }^{1}$--- Felix Kwame Aveh ${ }^{2}$--- Rebecca Addo ${ }^{3}$ \\ ${ }^{1,2}$ Department of Accounting, University of Professional Studies, Accra-Ghana \\ ${ }^{3}$ Department of Finance, Ghana Statistical Service, Volta Regional Office
}

\begin{abstract}
This is an exploratory study that investigates the financial management practices of 286 selected households in Greater Accra Regions of Ghana. The main objectives of the study are to examine the budgeting and budgetary control practices of the households and to identify the relationships that exist between the budget culture of a household and their educational level, stage, income, and savings/investment stock. Questionnaire was used in data collection and descriptive statistics such as cross tabulation and Chi-Square test of significance were applied to the data. It was found that most households do not prepare a budget for various reasons. Husband's dominance of the resource allocation and bargaining process was emphasized by the findings. The study found a significant relationship between household budgeting and level of saving, educational level, income level and age of household. Most households do not seek the assistance of finance experts in financial planning and decision making. We suggest that coordinated measures are put in place by relevant government agencies and finance professionals to boost the level of financial literacy among households and individuals since it has an implication for saving and wealth creation as well as family harmony and unity.
\end{abstract}

Keywords: Households, Financial management, Budgeting, Budgetary control, Ghanaian households, Family budget.

Received: 10 February 2014/ Revised: 9 April 2014/ Accepted: 25 April 2014/ Published: 3 May 2014

\section{Contribution/ Originality}

Finance management practice in households is a virgin research interest as most studies prefer to research into financial management phenomena in large, medium and small scale enterprises thus creating knowledge gap between financial management phenomena in business and non-commercial set ups. This paper aims to contribute and set the tone for the balance. 


\section{INTRODUCTION}

Finance is very critical resource to every organisation and so its management has attracted much attention in the management literature. In firms, funds are needed to acquire materials, assets and hire qualified workforce to achieve the firm's objective of shareholder worth maximization (Ross et al., 2002). In not-for-profit entities, funds are equally required for the organisation and operation of its activities towards increasing the welfare of the stakeholders. Financial management is broadly concerned with three issues: the kind of long term investments to make (capital budgeting decision), where to obtain the cash for the required investments (financing decision) and how to manage its cash and finance affairs in day-to-day basis (working capital management).

These decisions are vital in defining the success of an entity either in terms of profit maximization or value creations. Capital budgeting decision is decision as to which real assets the entity should acquire and it is central to the entity's success or failure (Brealey et al., 2001). Capital budgeting is the process of planning and managing a firm's long-term investments and in this process the financial manager tries to identify investment opportunities that are worth more than the cost of acquisition (Ross et al., 2001). The second major issue of concern to financial managers is how to obtain finance to fund the activities of the organisation. In general speaking, finance may be short term or long term. Short term finance is obtained from sources for which repayment is required within one year period and they are used to acquire inventories, pay bills, and met other short term obligation. On the other hand, long term finance is used to meet capital budget requirements of the entity and this may come from the shareholders or borrowed from variety of lenders in a number of different ways. Another important task of financial management is working capital management. Working capital describes a firm's short-term assets, such as inventory, and its short-term liabilities such as money owed to suppliers. Working capital management is a day-to-day activity that ensures the firm has sufficient resources to continue its operations and avoid costly interruptions.

Financial management practices in business enterprises differ from those in not-for-profit entities, even though the similarities are more profound. According to Dobbelsteen and Kooreman (1997), managing household finance is quiet different from managing corporate firm because of the deferring structures, stakeholders and goals. Financial management of households involves a diversity of decisions in connection with importance, frequency and the amount involved.

Dobbelsteen and Kooreman (1997) identify five different aspects of financial management of household: the household's financial allocation system, power play in final decisions, contribution toward household bill, and day-to-day management of household spending and control over small personal spending. Thus, financial management in household involves budgeting for household expenditures, providing funds to meet the budget, evaluating and controlling the spending (Hilgert and Hogarth, 2003). Furthermore, Hilbert and Hogarth use four financial practices 
within the household to explore the pattern of financial management practices and these include cash-flow management, credit management, saving, and investments. Empirical results provided by Dobbelsteen and Kooreman (1997) indicate that financial management is primarily determined by bargaining considerations within the households.

According to Landy (2009) household financial management involves the use of financial resources to achieve the goals of the household. It is a financial problem solving process managing financial matters wisely helps to avoid financial problems and proper and suitable financial planning using available resources are important. Landy (2009) identified some useful financial management strategies of households: to obtain maximum return or satisfaction from the money owned; manage money to meet spending and avoid waste; create savings of unspent money resulting from wise spending; face financial emergencies need; control what we have by obtaining protection or steps of protection to reduce financial loss; and to increase income by investing part of the unspent money.

The general goal of financial management in both business enterprises and not-for-profit entities like households is to increase the value of the stakeholders through optimal utilization of available resources to meet the entities goals. In particular, financial management within household aims at bringing about efficiency in the use of the limited financial resources to achieve the ever increasing needs of the family as well as creating saving for emergencies and investment for the future. Hilgert and Hogarth (2003) observe that households lack financial knowledge and expertise to manage their resources efficiently, landing some of them in precarious financial situations. Conspicuously, financial management is critical in achieving value for the households' money just as it is important in maximizing the value of shareholder in a firm.

There is abundance of research literature on financial management concerning business enterprises of all kinds and structures: small scale enterprises, medium scale enterprises, large scale enterprises and international corporations. All these studies emphasized the need for effective financial management in the accomplishment of a firm's goals; some also echoed the serious consequences of poor financial management in firms (McChlery et al., 2005; Kurfi, 2009; Abor and Quartey, 2010). However, studies relating to financial management in not-for-profit entity are rare because its importance has been down played (Blaze, 1996). It has been admitted that financial management of not-for-profits is similar to financial management in the commercial sector in many respects; however, certain key differences shift the focus of a not-for-profit financial manager. A for-profit enterprise focuses on profitability and maximizing shareholder value while not-for-profit organization's primary goal is not to increase shareholder value; rather to provide some socially desirable needs on an ongoing basis. Further, there is growing disinterest among the research community for financial management behaviours of households which serve as the basic unit of every set up, including the country as a whole. Evidence available demonstrates that financial management behaviours of households do not only foster the cohesion and mutuality within the household but also influence their savings and investment behaviours 
(Davis and Carr, 1992; Fagan and Brayman, 2011). The study is therefore intended to bridge this research gap by focusing on the financial management practices of the households in Ghana. The objects of the study are two folds. First is to survey the financial management behaviours of Ghanaian households in term of generation of financial resources, allocation of the resources, spending of the resources, custody for the resources and investment decisions. Second is to examine the role of financial experts in financial decisions of households.

The remaining part of the paper contains literature review, methodology, results and discussions and conclusions and recommendations.

\section{LITERATURE REVIEW}

\subsection{The Concept and Objectives of Financial Management}

Finance simply means the management of money or "funds". According to Meredith (2006) financial management is one of the several functional areas of management but it is central to the success of any business. This emphasizes the central role and position of financial management in relation to the other specific areas of business management. Meredith (2006) suggests that financial management is concerned with all areas of management, which involve finance not only the sources, and uses of finance in the enterprises but also the financial implications of investment , production, marketing or personnel decisions and the total performance of the enterprise. English (2000) confirms that financial management is concerned with what is going to happen in the future and its purpose is to look for ways to maximize the effectiveness of financial resources. Financial management involves raising the needed funds to finance the enterprise's assets and activities, the allocation of these scare funds between competing uses, and with ensuring that the funds are used effectively in achieving the enterprise's goal. All these definitions suggest that financial management involves planning, directing, monitoring, organizing, and controlling of the monetary resources of an organization. Financial management is about planning income and expenditure, and making decisions that will enable you to survive financially and it includes financial planning and budgeting, financial accounting and analysis, financial decision-making and action. There are three overarching divisions within the academic discipline of finance and its related practices:

- Personal finance. It refers to the finances of individuals and families concerning household income and expenses, credit and debt management, saving and investing, and retirement income security;

- Corporate finance. It relates to the finances of commercial organizations including corporations, trusts, partnerships and other entities; and

- Public finance. It deals with the financial management of domestic and international governments and other public entities. 
The craft of financial management is not limited to business entities; non-profit entities also require to management their financial resources economical, efficiently and effectively in pursuance of their goals (Mostahari, 2005). Where there is money, there is a need for financial management, not excluding households as the basic unit of organization. The main objectives of financial management are foundations or bases for comparing and evaluating the efficiency and effectiveness of financial management. Whereas the prime goal of financial management in businesses is to maximize the financial wealth of the business owners (McMahon, 2005), the basic objective of financial management in the not-for-profit entities, including households is to ensure value for money by securing economy, efficiency and effectiveness in their operations (Dobbelsteen and Kooreman, 1997). Ellis (1998) opines that if financial management in every sphere of life is done properly, with a view to achieving both cost effectiveness and broader development goals, it can play a powerful role in poverty reduction.

According to Meredith (2006) there are three key elements to the process of financial management: Financial planning, control and decision-making. Financial planning is about making sure that the organisation, including household can survive, making sure the money is being spent in the most efficient way, making sure that the money is being spent to fulfil the objectives of the organisation and being able to plan for the future of the organisation in a realistic way. In financial planning, management needs to ensure that enough funding is available at the right time to meet the needs of the organization. In conclusion, funds may be needed to invest in equipment and stocks, pay employees and produce goods and services for sales. In the medium and long term, funding may be required for expansion of the business. Financial control is a very important activity to help the business ensure that the business is meeting its objectives. Financial control addresses questions such as: Are assets being used efficiently? Are the assets of the entity secured? Does management act in the best interest of stakeholders and in accordance with entities' rules?

The key aspects of financial decision-making are investing, financing and distribution of returns. There alternative always of financing investment.

\subsection{Household Financial Management}

The American Heritage Dictionary of the English (2000) defines a household as a domestic unit consisting of the members of a family who live together along with nonrelatives such as servants, the living spaces and possessions belonging to such a unit. Household contain a person or group of persons occupying a single dwelling irrespective of their family ties, making room for nonfamily households. To Haviland (2003) household is the basic residential unit in which economic production, consumption, inheritance, child rearing, and shelter are organized and carried out; and the household may or may not be synonymous with family. A household includes all the persons who live in a single housing unit. A housing unit means a house, an apartment, a mobile home, a group of rooms, or a single room that is occupied or is intended for occupancy as 
separate living apartment. A house unit is a separate apartment in which the occupants live and eat separately from any other persons in the building and which have direct access from the outside of the building or through living room. Thus, household is constituted by a single family, one person living alone, two or more families living together, or any other group of related or unrelated persons who share living domestic living culture.

The relationship between wealth accumulation and financial literacy has received much less attention, mainly because of a dearth of information of financial knowledge levels in the population. Recently, however, there has been burgeoning research on the measurement of financial literacy and its effects on household behaviour (Kimball and Shumway, 2006; Lusardi and Mitchell, 2007; 2008; 2009; 2011). Interestingly, Hilgert and Hogarth (2003) conducted intensive study on the relationship between financial knowledge and household wealth, arguing that the relationship between financial literacy and household behaviour is important as individuals are increasingly being asked to take on responsibility for their financial well-being and their retirement preparation. However, researchers have found that individuals do not save enough for retirement (Bernheim et al., 2001). Obvious there is policy interest for understanding the extent to which financial education affects saving behaviour and the effectiveness of the types of educational programmes. Empirically the effect of financial education and the provision of information on saving behaviour is inconsistent (Lusardi, 2004). Cohe and Sebstad (2003) emphasizes the benefits of financial education for the poor households. They argue that the promotion of financial literacy in developing countries is timely and can be a win-win situation for poor people and financial service providers alike. Financial education can also help the poor households to build assets and increase wealth. Financial literacy skills can be applied in managing resources of the individuals, households, businesses, and communities. To them the ability to build assets is an essential ingredient in developing countries because they provide economic security. They also identified the financial requirements in the household life cycle, that is household formation, birth, education, marriage, old age and death as follows; working capital, productive assets, investments, asset protection, health and shock.

Ashraf (2009) recounted the sociological importance of household management from the intra-household model which seeks to interpret how house finance is managed in the various households as to who retains power in the marriage. Successful financial management in household, he argues, depends largely on three things. First, the distribution of work is needed in terms of finances. Second, a mutual agreement among households members expenditure items and levels. Members need to agree on a spending plan. This is usually done when related expenditure is not recurrent, suppose the decision to replace an old family vehicle with a new one after a few years. Thus, members need to discuss and agree on the need to be fulfilled, the common desire and the mode of delivery. Third, savings culture of the household. In this regards, the vision of the future becomes very important. Here the vision of the household will provide motivation and selection strategies that can help achieve future goals. 


\subsection{Budgeting in Households}

A budget is described as a plan of a household expressed in financial terms. It is usually in the form of a list of planned expenses and means of meeting those expenses. It is a plan covering savings borrowings and spending of households. A budget is an important concept in financial management that employed a budget line to illustrate the trade-offs between two or more goods. Budget supports the planning of actual operations by compelling managers to consider how the conditions might change and what steps should be taken now. It also helps to co-ordinate the activities of the organization by compelling managers to examine relationships between their own operation and those of other unit. Having a good household budgeting plan is the critical part to financial health. According to Davis and Carr (1992), in turning attention to the life cycle approach to household financial management, it is assumes that households in the various stages of the life cycle have different needs to be met and also argued that the financial resources and demands do not remain the same throughout the cycle and consequently financial management practices also change as people move from one stage of the cycle to another. Critical issues in household budgeting are who develops the budget? How it is developed? Who authorises it? And for non-budget expenditure who can give permission to spend money on items not budgeted for?

In a personal or family budget all sources of money are identified and expenses are planned with the intent of making ends meet. In consumer theory, an individual or household cannot meet all their wants and need in a particular period due to what is termed budget constrain. A personal budget is therefore a finance plan that allocates future personal income towards expenses, savings and debt repayment with the budget constraint.

\subsection{Investment Decisions}

The simplest version of the life cycle consumption model without bequests and uncertainty posits that households accumulate savings during their working careers up to their retirement, and de-accumulate wealth thereafter. This type of saving behaviour enables households to smooth their marginal utility of consumption over the life cycle. However, there are many reasons why household consumption and wealth follow patterns different than that predicted by the life cycle model, and the standard model can be easily adjusted to account for these reasons (Browning and Lusardi, 1996). For example, studies have highlighted the role of precautionary saving motives (Hubbard et al., 1995), longevity and bequests (Hurd, 1989), different economic opportunities across cohorts (Kapteyn et al., 2005), self-control problems (Laibson, 1997; Benartzi and Thaler, 2004; Ameriks et al., 2007), unexpected events (Venti and Wise, 1998; Lusardi, 2003), and health (Rosen and Wu, 2004).

Somewhat related to the subject of our study is the work by Chan and Stevens (2008) who indicates that households base their pension and retirement saving plans on limited and sometimes incorrect pension knowledge. The issue is whether financial literacy affects households' knowledge of pension and social security benefits. Using data from a sample of older 
US individuals, Gustman et al. (2010) found that there is no significant relationship between cognitive skills and knowledge of retirement plan characteristics and social security plan. However, there is a positive relationship between pension wealth and knowledge, but Gustman et al. (2010) argue that the causality is more likely to run from wealth to pension knowledge than the other way around.

\subsection{Hypotheses}

The study put forward five hypotheses based on the literature review.

$\mathbf{H}_{1}$ : Household budgeting has significant effect on the level of savings of the household.

$\mathbf{H}_{2}$ : There is a relationship between the education level of head of household and the household budget behaviour.

$\mathbf{H}_{s}$ : Income level of household influences decision to run a budget

$\mathbf{H}_{4}$ : The age of household influences budgeting behaviour.

$\mathbf{H}_{5}$ : Household with budget is likely to operate a joint bank account.

\section{METHODOLOGY}

\subsection{Research Design}

This is an exploratory research that surveyed the financial management behaviour among Ghanaian households. The study administered questionnaires to 400 households selected randomly from Greater Accra Region of Ghana. The Greater Accra Region is chosen for the study because it is the capital city of Ghana and has convincing cosmopolitan characteristics. The households were randomly sampled in order to give equal chance of representation. In all 292 questionnaires were retrieved with 286 useable, constituting a response rate of $71.5 \%$.

In this article the term household means a domestic unit consisting of the members of a family who live together along with nonrelatives such as servants, the living spaces and possessions belonging to such a unit. Similar to Haviland (2003) household is the basic residential unit in which economic production, consumption, inheritance, child rearing, and shelter are organized and carried out; and the household may or may not be synonymous with family.

\subsection{Construction of Instruments}

A questionnaire was design to cover five main issues: demographic characteristics, sources of household's income, budgeting and budgetary control, investment decisions and influence of experts in financial management. The items were developed through focus group discussions to ensure the relevance of the questions. The questions were pre-tested for understandability, relevance and reliability of the items. The result of the pre-testing was used to refine the final questionnaire administered. The internal consistency based on the average inter-item correlation was test using Alpha (Cronbach's) model, and a score of 0.76 was achieved. Reliability analysis helps to determine the reliability and adequacy measurement scales and the items that compose 
the scales. Likert scale of 1 to 5 was used to measure responses to rating of benefits and challenges of household budgeting. The data was analyzed with Software Package for Social Sciences (SPSS). The data was presented in frequency tables, means and cross tabulations. The chi-square test of statistics was used to test the hypotheses.

\section{RESULTS AND DISCUSSIONS}

\subsection{Demographic Characteristics of Respondents}

The demographic data in Table (panel I - VI) showed that over $47 \%$ of the households investigated are made up of husband, wife and children or other persons such as domestic servants. Approximately $21 \%$ of the households is made up of mother and children only. This is indicative of increasing trend of single parent households in the society of which mothers are the receiving end. Most of the households are between 10 and 15 years of existence, which we described as early growth stage.

Table-1. Demographic Characteristic of Respondents

\begin{tabular}{|c|c|c|}
\hline Demographics & Frequency & Percentage \\
\hline \multicolumn{3}{|l|}{ Panel 1: Composition } \\
\hline Husband and wife only & 73 & 25.5 \\
\hline Father and child(ren) only & 14 & 4.9 \\
\hline Mother and child (ren) only & 59 & 20.6 \\
\hline Other combinations & 5 & 1.7 \\
\hline Early beginning stage (1- 5years) & 39 & 13.6 \\
\hline Late beginning stage (6-10 years) & 55 & 19.2 \\
\hline Early growth stage (11- 15 years) & 101 & 35.3 \\
\hline Late growth stage (16- 20 years) & 69 & 24.1 \\
\hline Maturity Stage (Above 20 years) & 22 & 7.7 \\
\hline Average income ( GHc20,000 - GHc50,000) & 131 & 45.8 \\
\hline High income ( above GHc50,000) & 109 & 38.1 \\
\hline Total & 286 & 100.0 \\
\hline \multicolumn{3}{|l|}{ Panel IV: Accommodation type } \\
\hline Live together in own apartment & 32 & 11.2 \\
\hline Live together in rented apartment & 156 & 54.5 \\
\hline Live apart & 86 & 30.1 \\
\hline Others & 12 & 4.2 \\
\hline Total & 286 & 100.0 \\
\hline \multicolumn{3}{|l|}{ Panel V: Educational background } \\
\hline Tertiary education level & 190 & 66.4 \\
\hline Wife work and husband does not & 24 & 8.4 \\
\hline Total & 286 & 100.0 \\
\hline
\end{tabular}

Source: Field survey 2012. (Note: At the time of the study the exchange rate was GHc2.10 to $\$ 1$ ) 
The majority of the households are average income families (between GHC20,000 GHC30,000 a year) and most of them live together in a rented apartment. Further, most of the households are headed by the husbands, where is there is one and in most cases the heads have university degree or diploma. In $64 \%$ of the households, both the husband and the wife work and earn income and in $28 \%$ only the husband works.

\subsection{Sources of Income to Households}

The main sources of income to a household include husband's employment income $(74.5 \%$ of total income), Wife employment income (18.3\%) and other sources constituting average of $7.2 \%$. The other income sources identified and presented in Figure 1 are trading, consultancy, gaming, income from financial investment and transport (mainly taxi cabs). This emphasizes the point that husbands remains the main financiers of the household budget.

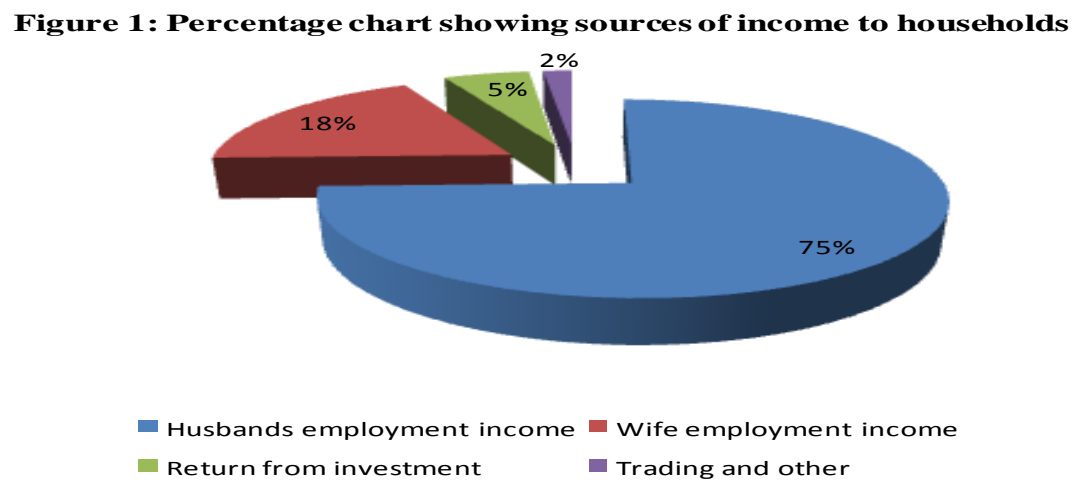

\subsection{Budgeting Practices among Households}

Resource allocation is a crucial element of financial management and budgeting is most common tool for allocating household resources economically, efficiently and effectively. In exploring this phenomenon, the respondents were asked the question: "Does your household prepare a budget?" The responses reveal that most households (76.2\%) do not have a budget for reasons displayed in Table 2. The most frequent reasons offered include lack financial knowledge in budgeting, irrelevance of budgeting to household management, dynamics of individual choices within the household and the uncertainty in predicting future events affecting the household activities.

The form of the budget varies among the households that have budget as shown in Table 3 (panel 1). In $57.4 \%$ of 68 households that confess having a budget, the budget is partly mental and partly written. Only $10.4 \%$ has the budget completely written. This practice inhibits their ability to control the budget. Further, the budget period among the households differ significantly ranging from daily to yearly. Table 3 (panel 2) indicates that majority of households $(51.5 \%$ ) 
operate a monthly budget period. This implies that most households are engaged in short term planning and this affects their ability to develop a long term plans.

Table-2. Reasons why Households do not prepare budgets

\begin{tabular}{lll}
\hline Reasons & Frequency & Percentage \\
\hline Lack of financial knowledge & 128 & 58.7 \\
\hline Irrelevant for households & 45 & 20.6 \\
\hline Uncertainty of future events & 24 & 11.0 \\
\hline Flexibility of choice & 24 & 9.6 \\
\hline Total & 218 & 100 \\
\hline
\end{tabular}

\subsubsection{Budgeting Process among Households}

The respondents were asked to provide a brief description of the budgeting process in their households and the summary response produced four main approaches. The first approach, described as participative approach, is found among only $8 \%$ of the respondents. Under this approach, the leader of the household (usually the husband) invites budget inputs from all members of the household prior to the start of the budget period, which is usually one month. The members submit their request list to the leader who puts them together as a draft estimate. The leader afterwards convenes a household meeting to discuss and review the estimates in light of the available resources for the period. The members are allowed to debate the budget and bargain for fairer allocation of resources. Amendments are made by consensus and the final budget for the period is approved. The authoritarian approach is the second approaches found among $22 \%$ of the households that prepare a budget. Under this approach the leader, most often the husband, drafts a proposal for household spending for the period based on anticipated income without the involvement of other members. A meeting is convened with the wife without the children for discussion and finalization of the budget. In such arrangement the wife usually has a weaker bargaining power in the debate and approval. This method is mostly used in households where the husband is the sole provider for the household.

The third approach found was termed envelop budgeting and it is the most widely used (among $62 \%$ of households). Here, there is no budget proposal made but a meeting is summoned for all members prior to the beginning of the budget period to discuss their plans for the period and then agreement is reached. However no formal budget is prepared. Every member keeps those budget items that concern him or her in mind. For example, where a school boy's request for new shoes is agreed upon, he has to keep it in mind to ensure that it is implemented during the budget period. In the same way amount approved for housekeeping is kept in the mind by the wife who is usually responsible for housekeeping. This promotes envelop accounting where each vote controller is responsible and accountable for moneys appropriated to him or her. The fourth approach found among $8 \%$ of households is termed partial budgeting. Partial budgeting approach is a budgeting approach in which recurrent items are not budgeted for however large spending 
are planned and budgeted for by the household. In this approach the concern will be how to get money to undertake the project such as putting up a building, buying vehicles or other substantial home appliances. As for the recurrent item, they are dealt with as and when the need arises.

Table-3. Form and Duration of Household Budget

\begin{tabular}{lll}
\hline Panels & Frequency & Percentage \\
\hline Panel I: Form & & \\
Completely written & 22 & 32.4 \\
Completely mental & 7 & 10.8 \\
Partly written and partly mental & 39 & 57.4 \\
Total & $\mathbf{6 8}$ & $\mathbf{1 0 0 . 0}$ \\
\hline Panel II: Duration & & \\
Daily & 8 & 11.8 \\
Weekly & 14 & 20.6 \\
Monthly & 35 & 51.5 \\
Quarterly & 8 & 11.8 \\
Yearly & 3 & 4.4 \\
Total & $\mathbf{6 8}$ & $\mathbf{1 0 0 . 0}$ \\
\hline
\end{tabular}

\subsubsection{Benefits and Challenges of Household Budgeting}

The study listed six benefits associated with budgeting and asked the respondents to indicate their agreement or otherwise on a Likert scale of $1-5$, where 1 represents strong disagreement and 5 representing strong agreement. The benefits were formulated through rigorous literature search and modification of known benefits of budgeting to corporate entities. The responses, as indicated Table 4, shows that all the benefits identified are very significant. Budgeting in household is believed to improve economy, efficiency and effectiveness in resource allocation in the household. It was also found that budgeting promotes savings and investment in households as the result of expenditure savings. A household that budgets is able to set its priority right, which enable it to channel limited resource to more pressing needs. Household budgeting reaches far more than financial management; it fosters family harmony and cohesion in a coordinated manner. Budgeting also instil financial discipline among household members which helps to eliminate wasteful and extravagance.

Table-4. Benefits of Household Budgeting

\begin{tabular}{lllll}
\hline Benefits & N & Range & Mean & $\begin{array}{l}\text { Std. } \\
\text { Deviation }\end{array}$ \\
\hline Helps household to set priority & 68 & 1.00 & 4.5735 & .49824 \\
\hline Improves resource allocation within the household & 68 & 1.00 & 4.8382 & .37097 \\
\hline $\begin{array}{l}\text { Enhances harmony and unity of goal of members in a co- } \\
\text { ordinate manner. }\end{array}$ & 68 & 1.00 & 4.5588 & .50022 \\
\hline $\begin{array}{l}\text { Promotes financial discipline among members } \\
\text { eliminating extravagance }\end{array}$ & 68 & 2.00 & 4.1765 & .77153 \\
\hline Promotes household savings and investment & 68 & 1.00 & 4.5882 & .49581 \\
\hline Promotes planning in the household management & 68 & 3.00 & 4.6176 & .71298 \\
\hline
\end{tabular}


However, the respondents have acknowledged several challenges they face in preparation and implementation of a household budgeting, as shown in Table 5. One major challenge faced in household budgeting is the negative effect of emotion and personal values in the allocation and bargaining process. For example, a wife may not take it kindly for a husband suggesting a cut in the appropriation for hairdo and the effect of the disagreement may extend beyond budgeting. Lack of financial knowledge of the preparers of the budget is also another significant challenge affecting household budget preparation. It is also believe that a strict implementation of household budget may limit the member's financial freedom and if not handled well can lead to serious family crisis. Budgeting also provides the opportunity for the stronger bargainer in the process to exert much control over the others. In most cases, the husband is accused of this tendency. Budgeting is also difficult in an environment where the boundaries of the household are undefined in a typical Ghanaian setting. In such cases, budgeting for contingencies such as funerals and remittance to relatives become extremely difficult hence downplaying the budgeting process.

Table-5. Challenges of Household Budgeting

\begin{tabular}{lcccc}
\hline Challenges & $\mathbf{N}$ & Range & Mean & $\begin{array}{l}\text { Std. } \\
\text { Deviation }\end{array}$ \\
\hline Lack of adequate financial knowledge & 68 & 2.00 & 4.3088 & .57969 \\
\hline Identification and estimation of income from various sources & 68 & 2.00 & 3.7794 & .80753 \\
\hline Limits member's financial freedom & 68 & 1.00 & 4.7941 & .40735 \\
\hline $\begin{array}{l}\text { Allocation and bargaining process is affected by emotions } \\
\text { and personal values }\end{array}$ & 68 & 1.00 & 4.8529 & .35680 \\
\hline $\begin{array}{l}\text { Imposition of budget on the household by the most power } \\
\text { bargainer. }\end{array}$ & 68 & 2.00 & 4.3824 & .64714 \\
\hline Frequent changes in household choices and plans & 68 & 2.00 & 4.3676 & .77082 \\
\hline $\begin{array}{l}\text { Estimation of contingency within the budget is very } \\
\text { difficult. }\end{array}$ & 68 & 1.00 & 4.3824 & .48958 \\
\hline
\end{tabular}

\subsection{Budgetary Control Practices of Households}

\subsubsection{Tracking of Actual Expenditures}

It is important for households to measure their actual spending to enable them evaluate budget performance. It was found that out of the 68 households that prepare a budget of some kind, 32 of them constituting $47.1 \%$ do not maintain any records of their actual spending. It is noted that $53 \%$ keeps some records but only $50 \%$ of these can be sure on the accuracy of the spending data they maintained. This is indicative that budgetary control is not effective in most of the households that have a budget. This indication is confirmed by the responses to the question: "Do you compare the actual spending to your budget?" More than $42 \%$ responded in the negative and $29 \%$ indicates that they compare the spending to the budget sometimes. The failure to control the budget may be due to the households' inability to maintain accurate records on their income 
and spending. This disposition would not only hinder the financial management of household but perhaps the recipe for high level of tax non-compliance in Ghana.

\subsubsection{Bank Accounts of Households}

In order to ensure proper control of households spending there is the need for a mechanism that allows for restriction on the use of cash resources of the households. The study therefore seeks to know how the households ensure proper custody of these resources. A large majority $(62 \%)$ of households do not operate joint bank account and this will inhibit spending control as each individual member of the household operates and controls his or her own cash sources. Approximately 22\% of households keep joint bank account for household transactions alongside separate individual accounts of members. This arrangement allows for some degree of control and flexibility in resource management. A small proportion of household also operate only one joint account and no individual accounts are allowed. Technically, this is ideal approach however it comes with associated problems of rigidity and restriction in private dealings.

\subsection{Involvement of Finance Experts in Household Financial Management}

When people are sick they go to the doctor and if they have a case they run to the lawyer, but where do people turn to when they are planning their finances? This motivates the paper to examine the extent to which households seek the services of finance experts such as accountants and financial analyst. The question was posed: "Do you engage the services of finance experts in your financial management issues?" Interestingly more than $80 \%$ of the 286 households responded in the negative citing various reason such as lack of knowledge about the availability of such services to households, the high cost charged by finance experts and the difficulty in accessing such professionals. This has implication for accounting and finance professionals to take advantage of the growing market by increasing their visibility and developing service package that suit needs of households and individuals.

\subsection{Hypotheses Testing}

The five hypotheses of the study were tested using Pearson Chi-square test at significance of $5 \%$.Cross-tabulation was carried out on each hypothesis to determine the strength of relationship between the variables. The test results are shown in Table 6 .

The p-value of 0.000 obtained for hypothesis 1 implies that there is a significant relationship between household savings and budgeting. We therefore accept the null hypothesis that at $5 \%$ significance budgeting influences the level of household savings. The test result also supports the rejection of the null hypothesis II since the p-value exceeds the 0.05 significance. We therefore reject the null hypothesis II and conclude that there exist a relationship between the educational level of the household head and household budgeting. Concerning hypothesis III, the test fails to 
support the null hypothesis and so we conclude that the income level of household influences the budgeting behaviour of the household.

Table-6. Test Results

\begin{tabular}{|c|c|c|}
\hline Null Hypotheses & Level of significance & P-value \\
\hline $\mathrm{H}_{1}$ : Households' savings is dependent of budgeting & 0.05 & 0.000 \\
\hline $\begin{array}{l}\mathrm{H}_{2} \text { : There is no relationship between the education level of } \\
\text { head of household and the households' budgeting } \\
\text { behaviour. }\end{array}$ & 0.05 & 0.097 \\
\hline $\begin{array}{l}\mathrm{H}_{3} \text { : Income level of households do not influence household's } \\
\text { decision to prepare a budget. }\end{array}$ & 0.05 & 0.706 \\
\hline $\begin{array}{l}\mathrm{H}_{4} \text { : There is no a significance relationship between the age of } \\
\text { household and budget preparation. }\end{array}$ & 0.05 & 0.126 \\
\hline $\begin{array}{l}\mathrm{H}_{5} \text { : Household budgeting does not influence the type of bank } \\
\text { accounts operated. }\end{array}$ & 0.05 & 0.506 \\
\hline
\end{tabular}

Null Hypothesis IV was also refused and conclusion is drawn that the age of a household has significant relationship with budgeting. It implies that the age of a household is a determinant of budgeting behaviour of the household. Finally, the null hypothesis V could not be supported by the findings, suggesting that the type of bank account maintained by a household does not depend on budgeting control behaviour of the household.

\section{LIMITATIONS OF STUDY}

One limitation of the study is the inconsistency in selecting the person who completes the questionnaires on behalf of the household and this may affect the responses to some extent. In most cases wives were the persons who completed the questionnaires on behalf of the household and therefore their responses may not be representative of the household as a unit. The study was restricted Greater Accra Regions of Ghana and therefore may not be the true reflection of the overall picture of the existing ten regions and therefore generalization power of the study is limited.

\section{CONCLUSIONS AND RECOMMENDATIONS}

Every entity, household is no exception, requires some amount of financial resources to operate optimally and these resources need to be managed economically, efficiently and effectively. Thus management of financial resources required research attention particularly where non-professional managers are involved in carrying out such function in emotionally inclined environment. Thus this study pioneers the exploration of how household funds are managed by accidental mangers, husbands and wives. It investigates the budgeting and budgetary control measures adopted by these households and the extent to which they seek expert assistance in financial matters. It was found that most households involved in the study do not prepare budgets for reasons various. It may stem from lack of financial management knowledge, 
unavailability of finance experts to assist them or mere disregard of the practice. It was also revealed that husbands remain the major financier of household budgets and thus assume stronger influence in the allocation and bargaining process within the households. Household budgeting is also seen to offer some significant benefits to those household that attempt one: it helps them to set priority, ensures optimal allocation of resources within the household, increases savings and investment of the households as a result of financial discipline and elimination of extravagance, among others. However, some serious challenges were adduced by the respondents including limitation of personal financial freedom, emotional influence in the bargaining process and difficulty in anticipation of contingencies in an environment without social boundaries. A test of statistics found a significant relationship between preparing a budget and level of savings and of households. The study however found significant relationship between budgeting and educational level, income level and age of households. It was also found that most household do not seek assistance of finance experts in their financial planning and decision making for reasons various.

We therefore recommend that the issue of financial management of households should be looked at seriously since it has an implication for savings and investments, and tax paying behaviour of the households. The agencies concerned such as Ministry of Gender, Children and Social Right Protection in conjunction with Ministry of Finance should organize financial literacy programmes for households and individuals to create much awareness for the need for good financial management in homes. The accounting and finance professionals should also design cost effective service packages that meet the needs of households and also enhance their visibility and accessibility to households and individuals. The professionals may also intensify public education on the need to properly manage the financial resources of households and individuals. In area of research, we encourage future researches to expand their coverage to determine the large picture of the issue of financial management of households. Future studies may concentrate on the dynamics of household allocation and bargaining process in those household that prepare and implement budgets.

Funding: This study received no specific financial support.

Competing Interests: The authors declare that they have no competing interests.

Contributors/Acknowledgement: All authors contributed equally to the conception and design of the study.

\section{REFERENCES}

Abor, J. and P. Quartey, 2010. Issues in SME development in Ghana and South Africa. International Research Journal of Finance and Economics, 39(8): 218-228.

Ameriks, J., A. Caplin, J. Leahy and T. Tyler, 2007. Measuring self-control problems. American Economic Review, 97(3): 966-972. 
Ashraf, N., 2009. Spousal control and intra-household decision making: An experimental study in the Philippines. American Economic Review, 99(4): 12451277.

Benartzi, S. and R.H. Thaler, 2004. Save more tomorrow: Using behavioral economics in increase employee savings. Journal of Political Economy, $112(1)$ : S164-S187.

Bernheim, D., J. Skinner and S. Weinberg, 2001. What accounts for the variation in retirement wealth among U.S. households? American Economic Review, 91(4): 832-857.

Blaze, J., 1996. Financial planning for not-for-profit organizations. New York: John Wiley and Sons.

Brealey, R.A., S.C. Myers and A.J. Marcus, 2001. Fundamentals of corporate finance. 3rd Edn., New York: McGraw-Hill.

Browning, M. and A. Lusardi, 1996. Household saving: Micro theories and micro facts. Journal of Economic Literature, 34(4): 1797-1855.

Chan, S. and A. Stevens, 2008. What you don't know can't help you: Pension knowledge and retirement decision-making. The Review of Economics and Statistics, MIT Press, 90(2): 253-266.

Cohe, M. and J. Sebstad, 2003. Reducing vulnerability: The supply of health insurance in East Africa. Available from www. ipcc-wg2.gov.

Davis, P.E. and R.A. Carr, 1992. Budgeting practices over the life cycle. Journal of Consumer Education, $10(1): 27-31$.

Dobbelsteen, S. and P. Kooreman, 1997. Financial management bargaining and efficiency within the household: An empirical analysis. De Economist, 145(3): 345-366.

Ellis, F., 1998. Survey article: Household strategies and rural livelihood diversification. The Journal of Development Studies, 35(1): 1-38.

English, J.W., 2000. Small business financial management in Australia, Sydney: Allen \& Unwin.

Fagan, B.E. and S. Brayman, 2011. Financial planning literature survey. Journal of Personal Finance, $10(2)$ : 109-140.

Gustman, A., T. Steinmeier and N. Tabatabai, 2010. Financial knowledge and financial literacy at the household level. NBER Working Paper No.16500.

Haviland, W.A., 2003. Anthropology. Belmont, CA: Wadsworth.

Hilgert, M.A. and J.M. Hogarth, 2003. Household financial management: The connection between knowledge and behaviour. Federal Reserve Bulletin, 89(7): 309-322.

Hubbard, R., J. Skinner and S. Zeldes, 1995. Precautionary savings and social insurance. Journal of Political Economy, 103(2): 360-399.

Hurd, M., 1989. Mortality risk and bequests. Econometrica, 57(4): 779-813.

Kapteyn, A., R. Alessie and A. Lusardi, 2005. Explaining the wealth holdings of different cohorts: Productivity growth and social security. European Economic Review, 49( 5): 1361-1391.

Kimball, M. and T. Shumway, 2006. Investor sophistication, and the participation, home bias, diversification, and employer stock puzzles. Mimeo: University of Michigan.

Kurfi, 2009. Corporate capital structure and lease financing practices of selected manufacturing firms in Nigeria. European Journal of Economics, Finance and Administrative Science, (7): 27-29. 
Laibson, D., 1997. Golden eggs and hyperbolic discounting. Quarterly Journal of Economics, 112(2): 443477.

Landy, M., 2009. Introduction to Household Financial Management. Available from http://www.slideshare.net/mandalina/introduction-to-household-financial-management

[Accessed 201206 15].

Lusardi, A., 2003. Planning and saving for retirement. Pension Research Council Working Paper No. 200314.

Lusardi, A., 2004. Saving and the effectiveness of financial education in Mitchell, O., and Utkus, S. Eds. Pension Design and Structure: New Lessons from Behavioral Finance. Oxford: Oxford University Press. pp: 157-184.

Lusardi, A. and O.S. Mitchell, 2007. Baby boomer retirement security: The role of planning, financial literacy, and housing wealth. Journal of Monetary Economics, 54(1): 205-224.

Lusardi, A. and O.S. Mitchell, 2008. Planning and financial literacy. How do women fare? American Economic Review, 98(2): 413-417.

Lusardi, A. and O.S. Mitchell, 2009. How ordinary consumers make complex economic decisions: Financial literacy and retirement readiness. NBER Working Paper No.15350.

Lusardi, A. and O.S. Mitchell, 2011. Financial literacy and planning: Implications for retirement wellbeing. Oxford: Oxford University Press.

McChlery, S., A.D. Godfrey and L. Meechan, 2005. Barriers and catalyst to sound financial management in small size enterprises. Journal of Applied Accounting Research, 7(3): 1-26.

McMahon, R.G.P., 2005. Financial management for small business. 2nd Edn., CCH Australia.

Meredith, G.G., 2006. Financial management of the small enterprise. Sydney, New South Wales.: McGrawHill.

Mostahari, A., 2005. An introduction to non-governmental organizations management. MIT: Iranian Studies Group.

Rosen, H. and S. Wu, 2004. Portfolio choice and health status. Journal of Financial Economics, 72(3): 457484.

Ross, S.A., R.W. Westerfield and J.F. Jaffle, 2002. Corporate finance. 6th Edn., New York: McGraw-Hill.

Ross, S.A., R.W. Westerfield, B.D. Jordan and C. Firer, 2001. Fundamentals of corporate finance. 2nd Edn., New York: McGraw-Hill.

Venti, S. and D. Wise, 1998. The cause of wealth dispersion at retirement: Choice or chance? American Economic Review, 88(2): 185-191.

\section{APPENDIX \\ QUESTIONNAIRE}

Financial management practices of Households in Ghana

Section A: Demographic characteristics

1. What is the composition of your household? (Please tick one) 
[ ] Husband and Wife only

[ ] Husband, Wife and children

[ ] Husband and children

[ ] Wife and children

[ ] Others

2. How old is your household? (please tick one)

[ ] Very early stage $(1-5$ years)

[ ] Late early stage (6-10 years)

[ ] Early Growth Stage (11-20 years)

[ ] Late Growth Stage (16 - 20 years)

[ ] Maturity stage (above 20 years)

3. Estimate the annual income of your households? (please tick one)

[ ] Below GHC20,000

[ ] Between GHC20,000 - GHC30,000

[ ] Between GHC 30,001 - GHC 50,000

[ ] Above GHC50,000

4. What type of accommodation occupied by your households? (please tick one)

[ ] Live together in own accommodation

[ ] Live together in rented accommodation

[ ] Live separate accommodations

[ ] Others

5. What is the highest educational qualification of the head of the household? (tick one)

[ ] Degree or diploma in business or finance related

[ ] Degree or diploma in other fields

[ ] Secondary education

[ ] Basic education

[ ] Others

6. Occupational engagement of the household? (tick one)

[ ] Both Husband and Wife work

[ ] Husband work, Wife does not

[ ] Wife work, husband does not

[ ] Both unemployed

\section{Sources of Household funds}

7. Please estimate the proportion of household income from these sources

Husband's employment income

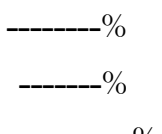

Wife's employment income $-\%$

Loans or credit 
Family business/investment income -------\%

Donations and gift

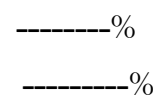

Others $\%$

8. If your household is engaged in business or investment, please indicate the kind of business you do or investment you make? (tick as many as applicable)

[ ] Buy and sell business (trading)

[ ] Consultancy (professional services)

[ ] Gaming (lottery etc)

[ ] Investment in financial Securities

[ ] Others

\section{Allocation of Resources}

9. In your household, do you make estimate of income and expenditure available for spending for a given period?

[ ] Y Y ] No

10. If you respond No, why don't you make estimate of your income and expenditure for a given period?

[ ] Lack of financial knowledge to do so

[ ] It is a waste of time since it is not adhered to anyway.

[ ] Uncertainty in making estimate of income and expenditures of a household

[ ] Flexibility in household choices

[ ] Others' specify

11. If you prepare a budget (estimate of income and expenditure), what duration does it cover? (tick one)

\begin{tabular}{|c|c|c|c|}
\hline ] Daily & [ & J Weekly & [ \\
\hline J Monthly & [ & I Quarterly & [ \\
\hline I Yearly & [ & I More thar & year \\
\hline
\end{tabular}

12. If you prepare budget, what form does it take? (tick one)

[ ] Completely mental

[ ] Completely written

[ ] Partly mental and partly written

13. Could you provide a brief description of the budgeting process in your household? 
14. What is the level of participation of the members of the household in the budget preparation process? (tick one).

[ ] All members participate actively

[ ] Husband is most actively involved

[ ] Wife is most actively involved

[ ] External persons actively involved

\begin{tabular}{llllll}
\hline Benefits & $\mathbf{1}$ & $\mathbf{2}$ & $\mathbf{3}$ & $\mathbf{4}$ & $\mathbf{5}$ \\
\hline Helps Households to set priorities & 1 & 2 & 3 & 4 & 5 \\
\hline Improves resource allocation within the household & 1 & 2 & 3 & 4 & 5 \\
\hline $\begin{array}{l}\text { Enhances harmony and unity of goal of members in } \\
\text { a co-ordinate manner. }\end{array}$ & 1 & 2 & 3 & 4 & 5 \\
$\begin{array}{l}\text { Promotes financial discipline among members by } \\
\text { eliminating down ex travagance. }\end{array}$ & 1 & 2 & 3 & 4 & 5 \\
\hline $\begin{array}{l}\text { Promotes household savings and investment } \\
\text { Promotes planning in the household management. }\end{array}$ & 1 & 2 & 3 & 4 & 5 \\
\hline
\end{tabular}

15. Below are some benefits a household derives from budgeting. Indicate your extent of agreement or otherwise to these identified benefits. (NB: $1=$ Strongly disagree $5=$ Strongly agree.)

16. What challenges do you face in preparation and implantation of a budget? Indicate how serious or not the following challenges are to your household. (NB: $1=$ not serious, $2=$ extremely serious).

\begin{tabular}{llllll}
\hline Challenges & 1 & 2 & 3 & 4 & 5 \\
\hline $\begin{array}{l}\text { Lack of adequate financial knowledge } \\
\begin{array}{l}\text { Identification and estimation of income from } \\
\text { various sources }\end{array}\end{array}$ & 1 & 2 & 3 & 4 & 5 \\
\hline Limits member's financial freedom & 1 & 2 & 3 & 4 & 5 \\
\hline $\begin{array}{l}\text { Allocation and bargaining process is affected } \\
\text { by emotions and personal values }\end{array}$ & 1 & 2 & 3 & 4 & 5 \\
\hline $\begin{array}{l}\text { Imposition of budget on the household by } \\
\text { the most power bargainer. }\end{array}$ & 1 & 2 & 3 & 4 & 5 \\
$\begin{array}{l}\text { Frequent changes in household choices and } \\
\text { plans }\end{array}$ & 1 & 2 & 3 & 4 & 5 \\
\hline $\begin{array}{l}\text { Estimation of contingency within the budget } \\
\text { is very difficult. }\end{array}$ & 1 & 2 & 3 & 4 & 5 \\
\hline
\end{tabular}

\section{Control of use of Household resources}

17. Do you keep record of the total expenditure of your household in any given period? [ ] Yes with precision 
[ ] Yes without precision

[ ] Not at all

18. How do you keep record of your expenditure in a given period?

[ ] We keep record of all household spending in a book.

[ ] Each member keeps separate record of his or her spending

[ ] We use a special expenditure tacking software

[ ] keeps partial record of only huge expenditures

19. How do you ensure the custody of your cash resources?

[ ] One common bank account is maintained for the household

[ ] One common household bank accounts plus separate members bank accounts

[ ] Different common bank accounts for different purposes

[ ] No common bank accounts but separate individual accounts

20. Who usually approves spending or payments? (tick one)

[ ] Husband approves it all the times

[ ] Wife approves it all the time

[ ] Mutual approval

[ ] Self approval

21. How would you describe your stock of savings?

[ ] High [ ] Moderately [ ] Low [ ]Zero

22. How would you describe your investment stock?

[ ] High [ ] Moderate [ ] Low [ ] Zero

23. Do you involve the finance professionals in your financial plans and decisions?

[ ] Yes, we seek advice and assistance from finance experts

[ ] Yes, we fall on friends who are financial experts for gratuitous advisory services

[ ] No, we do not involve financial experts at all.

24. Why don't you engage the services of finance professionals?

[ ] They charge too much

[ ] They are not visible

[ ] We don't know of the services the offer

[ ] We thought they work for only large firms.

25. In the future will you need the services of the finance experts?

[ ] Yes

[ ] No [ ] Uncertain 